Article

\title{
Social Capital in Community Organizing for Land Protection and Food Security
}

\author{
Pornsiri Cheevapattananuwong ${ }^{1, *}$, Claudia Baldwin ${ }^{1}$, Athena Lathouras ${ }^{2}$ and Nnenna Ike ${ }^{1}$ \\ 1 Sustainability Research Centre, University of the Sunshine Coast, Sippy Downs, QLD 4556, Australia; \\ cbaldwin@usc.edu.au (C.B.); nnenna.ike@research.usc.edu.au (N.I.) \\ 2 School of Social Sciences, University of the Sunshine Coast, Sippy Downs, QLD 4556, Australia; \\ TLathouras@usc.edu.au \\ * Correspondence: Pornsiri.chee@research.usc.edu.au; Tel.: +61-42-426-6489
}

Received: 25 January 2020; Accepted: 26 February 2020; Published: 28 February 2020

\begin{abstract}
Since 2016, the Thai Government has pursued a twenty-year national economic growth policy, Thailand 4.0, promoting innovation and stimulating international investment through the Eastern Economic Corridor (EEC) project. The EEC project involves significant land acquisition resulting in the need to relocate villagers with potential impact on food security in a major food production area. This research explored the concerns of a local farming community regarding the potential loss of their farmland and means of livelihood under the EEC project using a case study in Ban Pho District of Chachoengsao (CCS) province. It described their resulting action to protect their farmland using community organizing. Data was collected through documents, observation and semi-structured interviews of key stakeholders. The results demonstrate the role of social capital in community organizing. We contend that high social capital stock is a necessary precursor to create conditions for community members to take steps to defend and protect their interests. This paper contributes to a deeper understanding of the role of social capital in community organizing in cases involving natural resource management.
\end{abstract}

Keywords: land use; food security; social capital; community organizing; EEC Thailand; land protection; economic development

\section{Introduction}

Globally, national governments implement policies to generate and sustain economic growth and development by increasing productivity and improving the social and political wellbeing of their nation. One measure employed by government to promote economic growth is through infrastructure spending as a catalyst to boost productivity and enable businesses to operate as efficiently as possible and thus, stimulate the economy. For example, in 2009, the United States provided federal government spending exceeding $\$ 80$ billion for highways, bridges, and roads to spur economic growth and help create construction jobs impacted from the Great Recession [1]. A dilemma exists when such development has significant impacts on local communities. Support is required to ensure a just transition occurs, one that protects the environment and essential resources for communities.

Likewise, to increase economic performance and growth [2] of the country, the Thai Government has, since 2016, pursued a national economic growth policy aimed at stimulating international investments by promoting technology and innovation expected to provide economic benefits to the Thai economy through the construction of infrastructure such as roads, high-speed railway, and power plants in the Eastern Economic Corridor (EEC). These projects involve significant land acquisitions, which often result in the relocation of villagers and impact on their means of livelihood and social wellbeing. 
Inequitable economic development policies enable negative practices such as 'land and/or water grabbing' resulting in rapid urban settlement and changing land uses including industrial pollution and reduced access to adequate quality water. Land and water degradation are incompatible with agricultural production and food security [3-5]. Small-holder agriculture is essential to a healthy diversified economy [4].

The Food and Agriculture Organization (FAO) define food security as "a situation that exists when all people, at all times, have physical, social and economic access to sufficient, safe and nutritious food that meets their dietary needs and food preferences for an active and healthy life" (n.p) [6]. Food production can also be disturbed by large-scale land acquisition by domestic and transnational companies investing in plantation estates. In fact, some scholars have argued that land or water grabbing is a new form of colonization, where governments collaborate with international companies to control food production without consideration of the land rights or freshwater ownership of the local communities or the social and environmental impacts of their activities to the community $[7,8]$.

Given the importance of food for sustenance and food security, a just governance process for land and water resource access and security is crucial, as well as the need to implement "processes that work directly with the community and allow for greater community input to decision-making" [9]. Moreover, a just transition is one where communities work to make their own needs known using techniques such as community organizing.

Therefore, this study explores concerns of a local farming community regarding the potential loss of their farmland under the Thai government's Eastern Economic Corridor (EEC) project, and analyses the resulting action to protect their farmland through the lens of community organizing. Our unique contribution is in identifying the role and importance of social capital networks in community organizing.

\section{Conceptual Framework}

This research uses the community development method of community organizing to describe the community-initiated process to protect valuable farmland in the Ban Pho district of Chachoengsao province in Eastern Thailand. Community organizing is the process of people mobilizing and increasing their people and political power to solve a range of local problems [10-14]. It is a process used for political action when people confront injustice or seek economic and social opportunities [15-17]. It is also considered a process of power building and political education for people [17]. This research further draws on social capital theory to provide insight into relationships that are beneficial to supporting and sharing resources and information [18]. Drawing on social capital theory and using community organizing processes helps to explain the proactive and positive approach local residents in the case study are using to address perceived injustice by the government's social policy initiative.

\subsection{Social Capital}

Understanding the way that social capital functions in a community can provide a basis for identifying where and how to invest in community organizing. Social capital explains types of collaboration among actors and facilitates mutual support. Social capital was initially articulated by Bourdieu (1992) and expanded on by Putnam (2000). It is defined as relationships and collaboration among actors, which lead to trust, engagement, support, sharing of information and resources in their network [18-22], and achievement of common goals [23]. It relates to the norms and networks that enable people to act collectively [24]. Bourdieu believed social capital relates to self-motivated purposes invested by an individual such as a friendship network or institutionalized relationships such as in organizations or schools $[18,20]$. In contrast, Putnam argued the social capital from a communitarian or social perspective $[18,19]$, introducing concepts of bridging and bonding social capital. Woolcock and Narayan (2000), further contributed 'linking' to social capital theory [24]. The bridging dimension denotes the relationships among heterogeneous social groups such as those found amongst colleagues and acquaintances, while the bonding dimension is described as homogenous social relationships 
like those found amongst family, friends, and neighbors $[18,20]$. The former is referred to as thin trust, while the latter represents thick trust [18]. Linking social capital illustrates the nature of social interactions between agencies and communities or authorities and policy actors at various levels, which influence policy development [21,24-26].

Many scholars argue that social capital contributes to understanding, trust, respect, values, and norms among network members, and affects the quality of networks or groups, which in turn affects members' sense of empowerment and collaboration [21-23,25-28]. Information sharing among neighbors, for instance, is a measure of social capital and can lead to constructive neighborhood alliances [29]. Positive social capital can also influence behavior and attitudes of individuals in communities as they respond to environmental problems and assist in environmental or co-management policies [21].

In summary, social capital is a theory that aids collaboration and the building of trusting relationships among community members, who can influence positive outcomes in their communities. One might argue that having various forms of social capital is a necessary precursor to create conditions for community members to take steps to defend and protect their interests.

\subsection{Community Organizing}

Alinsky (1989), the founder of community organizing, believed in democracy as a means to social justice. He encouraged education to build human capacity and empowerment. He developed training tools for community organizers to help people understand their interests and identify collaborative alliances [17]. Alinsky also explains the roles that community organizers have to learn-how to assist people to understand their interests and how to build alliances for collaboration $[15,17]$. Further, Brown (2010) argues that community organizers play two main roles: firstly, to build organizations and develop leaders to take responsibility, be accountable, and practise dealing with issues rather than relying on someone else. Secondly, to search for and develop leadership skills in the team to play multiple roles and function interdependently. In addition, Brady and $\mathrm{O}^{\prime} \mathrm{Connor}$ (2014) underline that the process of community organizing has five stages of practice.

These include:

- Motivation: actors need the motivation to seek a solution when community members suffer injustice;

- Community building: community members identify the issues and raise awareness, so others understand and gain knowledge about their problems;

- Planning: members organize a plan and set a goal;

- Mobilizing: organizers engage with community members, build the power of people, using various tactics including negotiation with policymakers in order to achieve their goal; and

- Outcome: members report the result.

Community organizing can be applied to a bottom-up community action to address collective issues that impact on a community. A recent example of community organizing as a bottom-up approach relating to food security occurred in Graceville, a suburb of Brisbane, Australia, where a local group was stymied in their efforts to establish a community garden where residents could come together to grow food to eat [30]. In this instance, the community built an alliance with a local government councilor and using the councilor's power base, they employed the tactics of confrontation as well as partnership building to achieve a socially just outcome for the local community [30]. Furthermore, the concepts of linking social capital can be seen in this example, where local government policy was changed as a result of the community organizing process. When people are highly motivated, it can improve the success of community organizing and its ability to influence people.

These processes and activities of facilitation are targeted to build trust among participants and can provide them with a sense of empowerment [11]. Community organizing is most successful if it builds on and strengthens existing social capital and social networks. Moreover, understanding where strong 
social capital exists in an area provides a foundation for community organizing to build upon [31]. It can also reveal where organizers need to direct more attention [32]. Social networks play an important role for organizers to use in organizing and empowering people for social change [11,13,33]

Land-use changes that affect food security provide a strong motivating factor for organizing communities to seek fairer solutions especially in the context of rapid economic development leading to a potential loss of land and livelihood.

Through the conceptual framework of social capital and community organizing, this study explored how local communities in the Ban Pho district of Chachoengsao province in Thailand, mobilized to protect the likely loss of their farmland and means of livelihood, as well as maintain their existing social networks and relationships.

\section{The Case Study and Methods}

\subsection{An Overview of the Eastern Economic Corridor Project}

According to the Bank of Thailand, between 2012 and 2016, the average economic growth rate in Thailand was 3.5\%, and its projected that the Thai economy will remain in the middle-income bracket for the next 30 years [34]. As such, to boost economic performance [2] and move towards greater wealth, the Thai Government developed the Thailand 4.0 policy, a twenty-year strategy targeted at economic growth by promoting technology and improving innovation in the Eastern Economic Corridor (EEC). The EEC plan supports industrial sectors in three provinces: (i) Rayong, (ii) Chon Buri, and (iii) Chachoengsao (CCS) in Eastern Thailand (Figure 1, below).

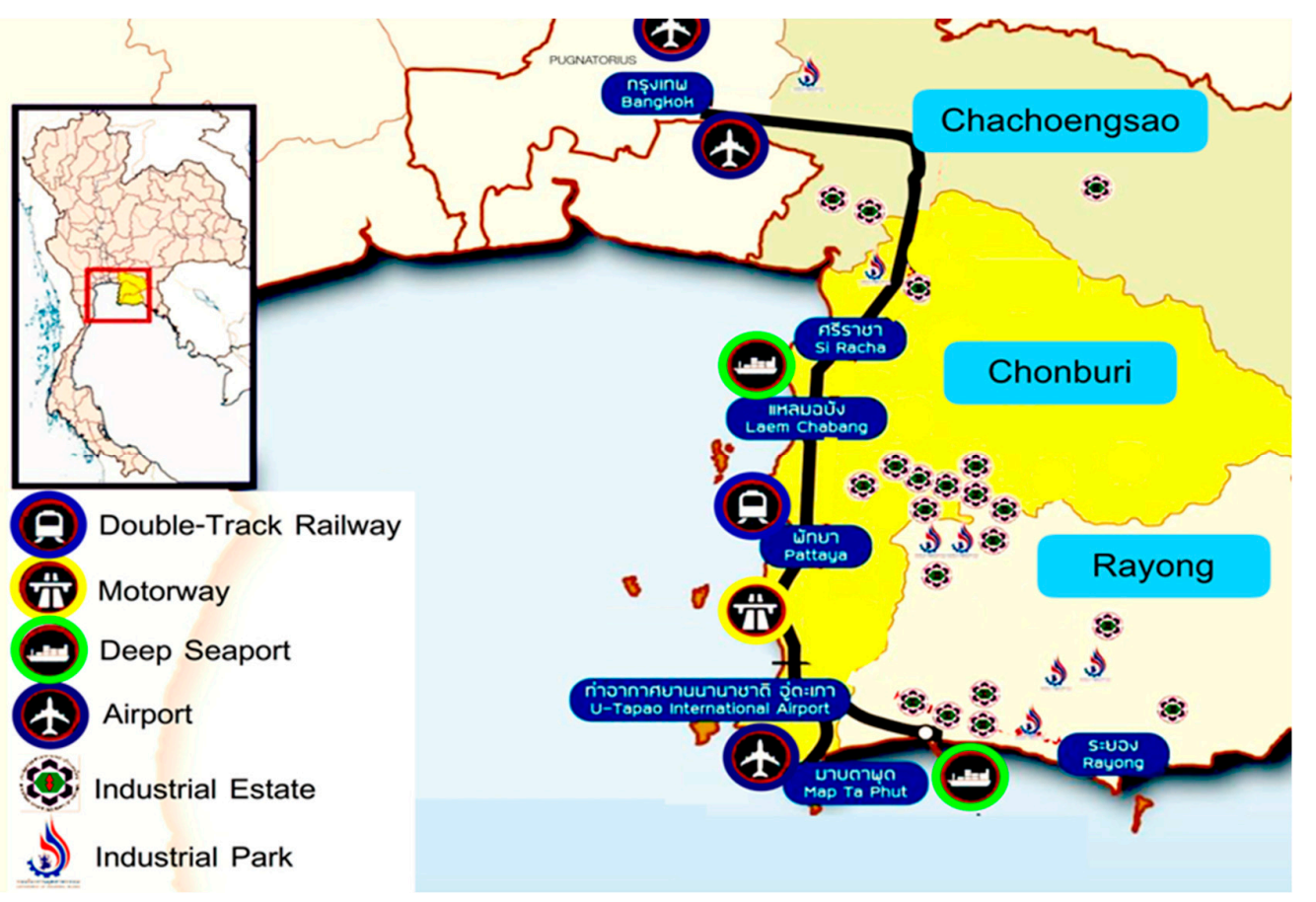

Figure 1. Map showing the three provinces in Eastern Thailand designated for the delivery of the Eastern Economic Corridor (EEC) project. Source: Thailand Board of Investment.

Thailand 4.0 is expected to provide economic benefits to the EEC provinces and the Thai economy in general through the construction of infrastructure such as roads, high-speed railway, and power plants [35].

Although the EEC project is yet to be implemented in CCS, local residents of the province are concerned about the potential impact of the project on their community considering the economic, social, and environmental impacts already being experienced in other areas where Eastern Seaboard 
Industrial Estate projects have been implemented. Some of the outcomes include: pollution and water grabbing in the Rayong province, resulting in health problems and reduced means of livelihood [36-40]; and impact on cultural values due to heavy commercial traffic and noise from Map Ta Put industrial estate, which affects people walking to temples and monks conducting their daily meditation. The need to install glass windows and doors to reduce traffic noise significantly alters the traditional architecture of local Buddhist temples [36].

Another example of economic reform policy in Southeast Asia that had significant economic, social and environmental impacts is the Doi Moi policy in Vietnam [40]. In a country where $70 \%$ of the population live in rural areas and are dependent on small-holder agriculture, large land acquisition in ThuaThien Hue province affected food security and livelihood, with consequent outmigration of men to urban areas to earn an income [41]. Further, land development resulted in the degradation of rice fields, fisheries and mangroves, and the loss of forests which consequently decreased biodiversity and increased greenhouse gas emissions [42]. The Thi Vai Estuary and the Can Goi Mangrove Forest in Vietnam were also affected by industrial wastewater emission and oil spills as a result of the project [40].

\subsection{Case Study Area-An Overview of Ban Pho District of Chachoengsao Province}

Ban Pho is one of the 11 districts in the CCS province. The district is located about $40 \mathrm{~km}$ east of Bangkok in Eastern Thailand (see Figure 2, below). The population of CCS in 2017 was 709,889 persons with Ban Pho having a population of 37,749 (5.3\% of CCS) [43].

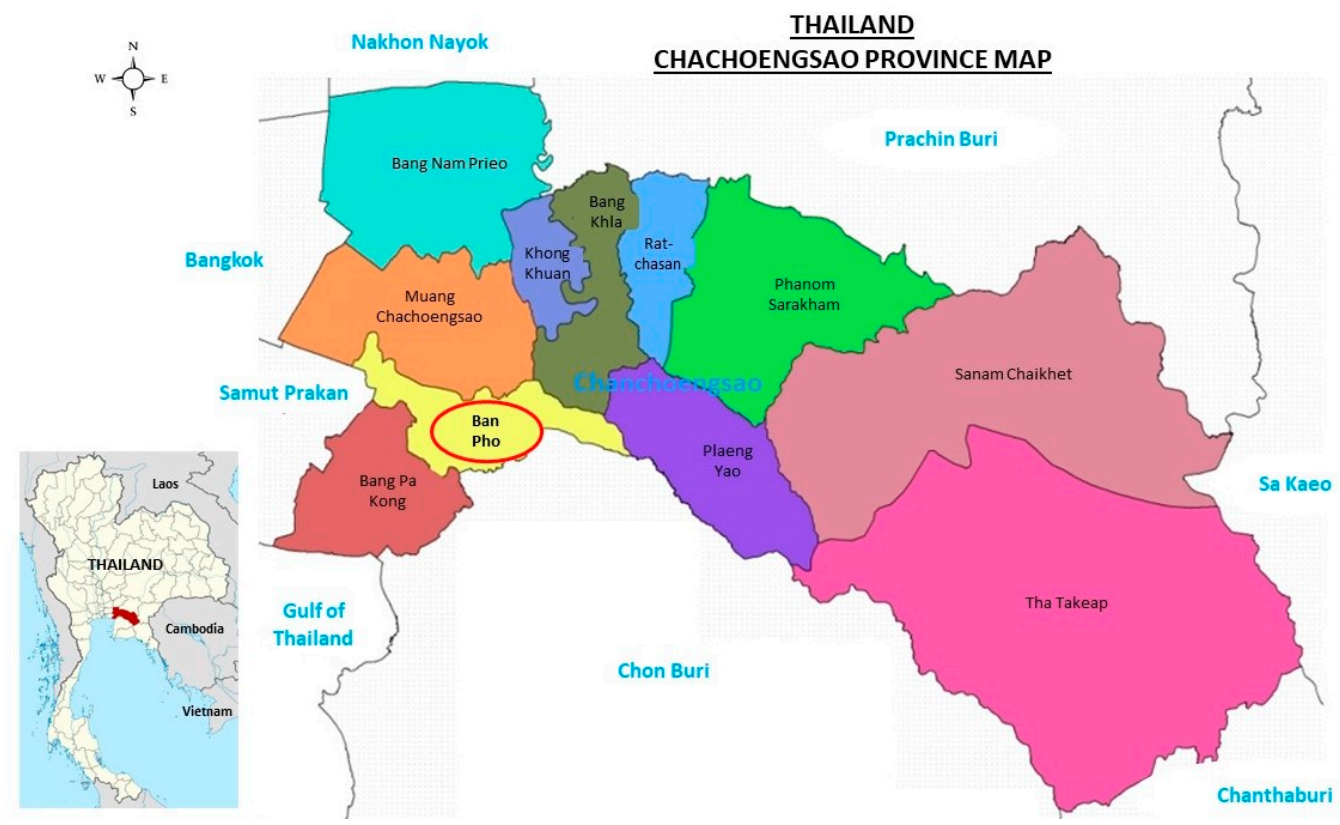

Figure 2. Map showing Chachoengsao (CCS) province including the districts of Ban Pho for context (source: modified from https://en.wikipedia.org/wiki/Chachoengsao_Province and https://dmcrth.dmcr. go.th/mcra2/aboutus/444/).

CCS's favorable weather and fertile soil support large commercial production of prawns, coconut, and a variety of fruits consumed in Thailand. In the western part of the CCS province lies the low river plain of the Bangpakong River, which is used extensively for rice farming. The Bangpakong River is the most essential watershed in Eastern Thailand because it is the main water supply for irrigation for agriculture, animal farming, and industries [44,45]. According to the World Resource Institute (WRI), the EEC project will increase risks to the Bangpakong River basin's water and food security due to environmental and social change by 2030 [46], which will have broader, and far-reaching consequences across the region. The industrial estates to be constructed in the EEC areas are likely to produce significant industrial waste and risk of pollution, which will affect over 709,889 people in the CCS 
province if insufficient controls are in place. There is already evidence of pollution and water grabbing occurring in the Rayong province, one of the three EEC target areas [47], where work is being carried out on the Eastern Seaboard Industrial Estate project.

The CCS province is also widely known for its abundant fish species (barramundi [48]), and the origin of the Jasmine-Rice gene or Jasmine 105 [49]. Further, the best of Nam Dok Maie (mangoes) grown in this province are exported to many countries, as well as eggs produced in the CCS are the greatest number in Thailand [50]. Hence, the livelihood of many local people in the CCS province depends on farming, fishing, and related agricultural jobs. In a nutshell, the CCS province is important to the Eastern Thailand regional economy and the country in general.

Nonetheless, the CCS region was chosen by the Thai government for the EEC project because of its strategic location. The province is close to existing airports, port, railways, and industrial estates, such as vehicle industries, providing a logistical transportation system to support economic development among the Southeast Asia countries [45]. Under the EEC project, the Nong Teen Nok area within Ban Pho was targeted to be an inland container depot (ICD), forming a part of the logistic and transportation hub as the province provides vital land, air, sea, and railway connectivity to other Southeast Asian countries of Cambodia, Laos, and Vietnam.

In 2012 the Nong Teen Nok local area was zoned for agriculture and fishing in the city plan. However, in 2018 it was changed to become a vital transportation hub (Figure 3, below).

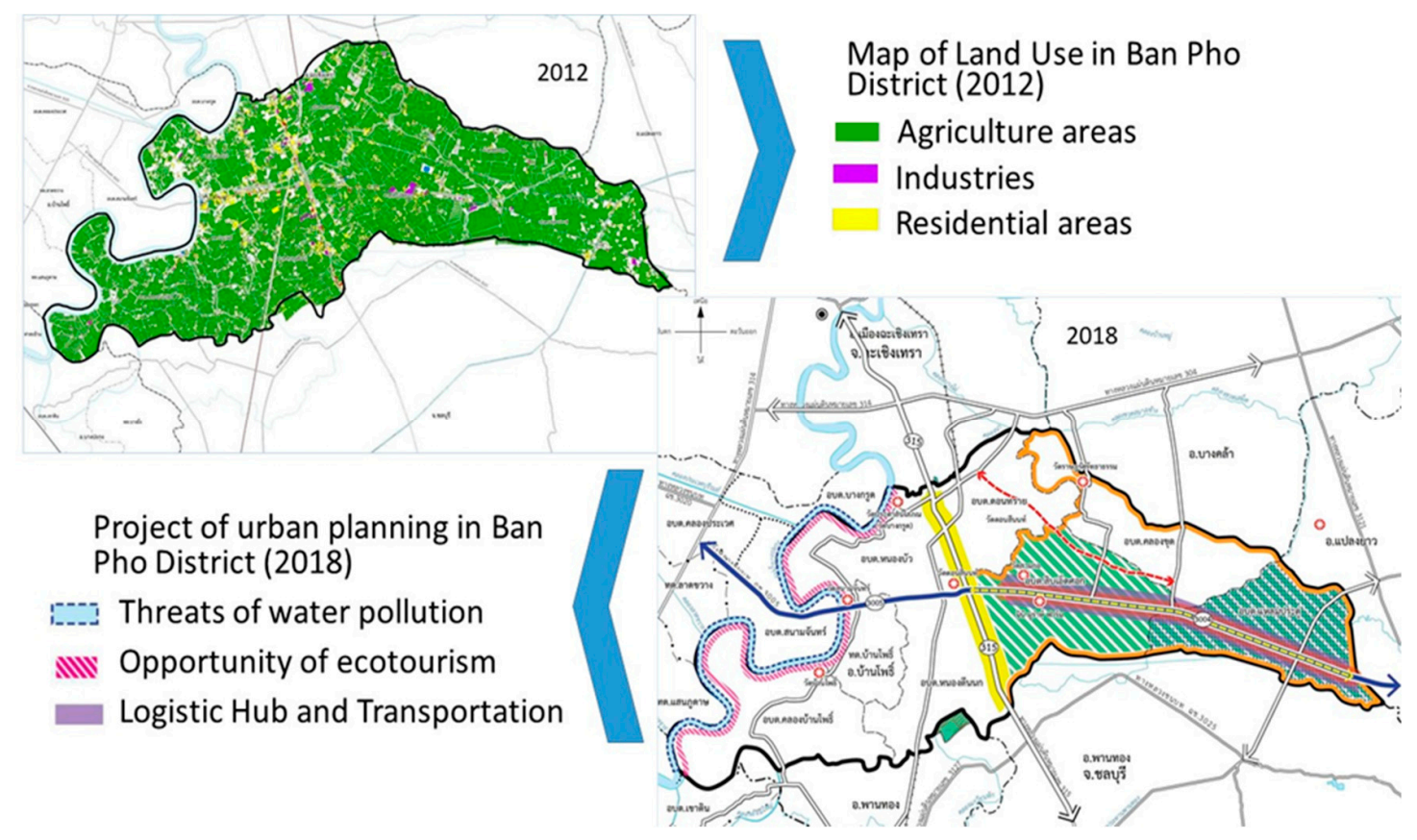

Figure 3. Map of land use in Ban Pho district in 2012 and 2018. Source: Department of Public works and Towns and Country Planning.

This change in zoning from 2012 to 2018 was brought about when the government enacted the Eastern Special Development Zone Act on 10 May 2018 (during the coup from 2014 to 2019). This allowed the Department of Public Works and Towns and Country Planning to change the city zoning plan from rural land use to industrial land use to accommodate the implementation of the EEC project within one year [51]. This land use zoning change will have significant environmental impacts and transform the community, which depends on agriculture and fishing for their livelihood.

These environmental concerns would be raised by the community during the EEC's request for Environmental and Health Impact Assessment (EHIA) approval, normally before commencement of any of the construction projects (such as the ICD). However, the EHIA had not begun at the time of 
data collection, although land acquisition and a search for investors were already underway. This indicates that the government is forging ahead with its plans without a thorough impact assessment.

It also reveals the government's plan to vigorously pursue the actualization of the EEC projects, despite any impact assessment. Notably the Policy Committee can override recommendations made in an impact assessment. Section 9 of the Eastern Special Development Zone Act states:

"If, in undertaking any act in the interests of the development of the Eastern Special Development Zone, the Policy Committee is of the view that any law, rule, regulation, by-law, notification or order causes inconvenience or delay, is redundant or creates an undue and excess burden, or in case of any other problems or obstacles, the Policy Committee shall propose such matter to the Cabinet for consideration of the amendment of such law, rule, regulation, by-law, notification or order, or for the enactment of a new law to ensure that the development of the Eastern Special Development Zone be carried out efficiently, conveniently, and promptly ..."

Following the quick implementation of the policy in November 2018, the consultant company, (contracted to deliver the project) alongside EEC officials began acquisition of land at Nong Teen Nok. A public hearing was held in late 2018 to engage with local residents relating to land acquisition. However, little information or clarity on the government's land compensation or relocation plans was provided to local residents.

A significant parcel of land will be required by the government to construct the new ICD at Nong Teen Nok (around 700 rai or 112 hectares) [52,53] and will result in around $7 \%-10 \%$ of good food production at this area lost to infrastructure and industry. This raises concerns about potential impacts of this project on the economic and social wellbeing of villagers who are likely to lose their farmland, means of livelihood, as well as their existing social networks by being relocated to another site.

Not only does the Thai government aim to lift Thailand out of its middle income trap, as a member of the United Nations (UN) it is working to achieve the UN Sustainable Development Goals (SDGs). The EEC development project priorities align with two key relevant SDGs: Goal 8-promoting sustainable economic growth, and full, productive employment; and Goal 9-building resilient infrastructure, promoting inclusive and sustainable industrialization, and foster innovation [54,55]. Rapid growth, though, can have unintended consequences that affect the achievement of other SDGs [7,8,42]. As food is a basic human need, a just governance process for land and water resource access and security is crucial.

Whilst Southeast Asian countries, including Thailand, are trying to improve their economic growth at the macro-level through rapid economic development policy, an inadvertent consequence is that land acquisition, and land and water grabbing affects local food security at the micro-level. It thus affects a country's ability to attain other SDGs, such as: Goal 2-reduce hunger and achieve food security; Goal 3-healthy lives; Goal 6-sustainable management of water and water and sanitation access; Goal 11-inclusive, safe, resilient, and sustainable human settlements; and Goal 12—sustainable consumption and production.

In summary, the economic policy implementation is a threat to the community's economic, environmental, and social conditions. We explored how local communities in the Ban Pho district used community organizing to address their concerns. We drew on social capital concepts to explain the positive contribution that networks of community relationships can have for a community.

\subsection{Methods of Research}

This qualitative research is a part of a larger doctoral project that studied several case study locations. This article presents findings from one of the case study locations, Ban Pho district. The research used mixed methods including document reviews, observation, and semi-structured interviews [56] to cross-validate information. 
Documents reviewed included the Eastern Special Development Zone Act 2018 (to understand the regulation and laws backing the EEC project), local newsletters, posters, leaflets, and general communication channels used to provide information to local residents about the EEC projects.

First hand observation was also used at eight local activities in Ban Pho, such as community meetings, a ceremony of the royal coronation of the new King, environmental conservation events, cultural and religious events, youth group activities, and an EEC public hearing in CCS. These meetings provided the researcher with understanding of the roles of participants and the dynamics in the relationship of local stakeholders.

Semi-structured interviews allowed the researcher (first author), a native Thai speaker to ask guided open-end questions [57] to 25 participants (16 males and 9 females) in the Ban Pho district. Participants were identified for their role and ability using the snowball technique, to provide insight into the issues, policy, and practical context for the study. Participants were recruited from diverse groups: civil society groups, local government officers, and members of the business sector. This enabled a variety of perspectives and limited researcher bias. In addition, the participants were recruited based on three criteria. Firstly, participants were in local roles or positions, relating to the topic, such as economic development, industrial expansion, or water and food security. Secondly, participants were impacted or likely to be impacted by the EEC projects, such as experiencing problems like pollution or land acquisition in the case study area. Thirdly, the sample was limited to people who had lived in the area for three or more years because the EEC was formed in 2016, and people who lived and worked in the area for that length of time were able to offer detailed perspectives to the changes occurring in the community due to the policy.

Participants gave their consent and were interviewed for approximately $45 \mathrm{~min}$ in a place comfortable to them. The information collected from the interview was audio-recorded, transcribed, and results were analyzed via NVivo software using categories derived from the themes relating to the issues of land protection for food security. Each participant was de-identified and given a unique identifier. Triangulation was employed to validate results and check accuracy of analysis by comparing observations, interviews, and documents. Data for the study was collected in mid-2019, which also coincided with the appointment of a new Thai cabinet after the election on 24 March 2019.

\section{Results and Discussion}

Overall, some participants acknowledged the potential benefits of the project in the Ban Pho district, including the ease of transportation and efficient mode of travel if high speed rails and new highways are built; opportunities for job creation in CCS; and the project signifying change/or growth for the community.

For example, one participant stated:

"The positive aspect of the EEC projects is that people in CCS will not need look for work far away from home such as Bangkok because the industrial sectors will come here. It is close to our home" (BP 022).

Other participants provided both positive and negative commentary. For example, one participant stated that while the EEC projects might be beneficial to young adults and those with education, this might not be the case for older adults and persons with no training. There were opinions that tourism, which currently exists in CCS would provide more sustainable employment creation rather than construction.

"EEC helps the economy to grow. This is positive for young local people to gain work in factories when they graduate but how about middle age and old people? It is difficult for them" (BP 016).

"If we talk about EEC, heavy industries will be good in the short term. It is not sustainable. I think, if we are looking for sustainability, tourism will be an opportunity. Currently, many 
people come here because they want to see rural areas and nature such as fireflies and Irrawaddy dolphins at the Bangpakong River more than any materials or modern buildings. Tourism helps local people get jobs too" (BP 002).

Although the EEC project can lead to job creation and economic growth, many residents who rely on the environment for their livelihood expressed concerns about the potential impact of these projects for themselves, family, and the community. As such, through the process of social capital and community organizing these residents mobilized together to seek solutions to their common issues.

\subsection{Social Capital in Community Organizing}

\subsubsection{Motivation}

Due to the ICD in the Nong Teen Nok area, participants in this area were motivated by the potential loss of their source of livelihood and had a shared concern about relocating to a new area that may be different from their current environment, and may not suit their livelihoods. They had also lost trust in the public hearing process due to its rapid speed, and this too fueled their motivation to act.

Concern About the EEC Project at Nong Teen Nok, Ban Pho District

Most of the villagers lease the land, which they use for prawn farming and agricultural purposes (see Figure 4). During the minimal engagement process carried out with the local community (following the quick enactment of the Eastern Special Development Zone Act), the EEC representatives, rather than listening to the local people, informed them that Nong Teen Nok would be an ICD area to support the EEC project. As such, some villagers were told they had to move to alternative settlements provided by the government. They worried about their livelihood and were confused about relocating to a new settlement. During the public hearing, the villagers were asked to sign their names to indicate attendance at the public hearing but they later found out that their signature was used instead to indicate the villagers' agreement to the ICD project.

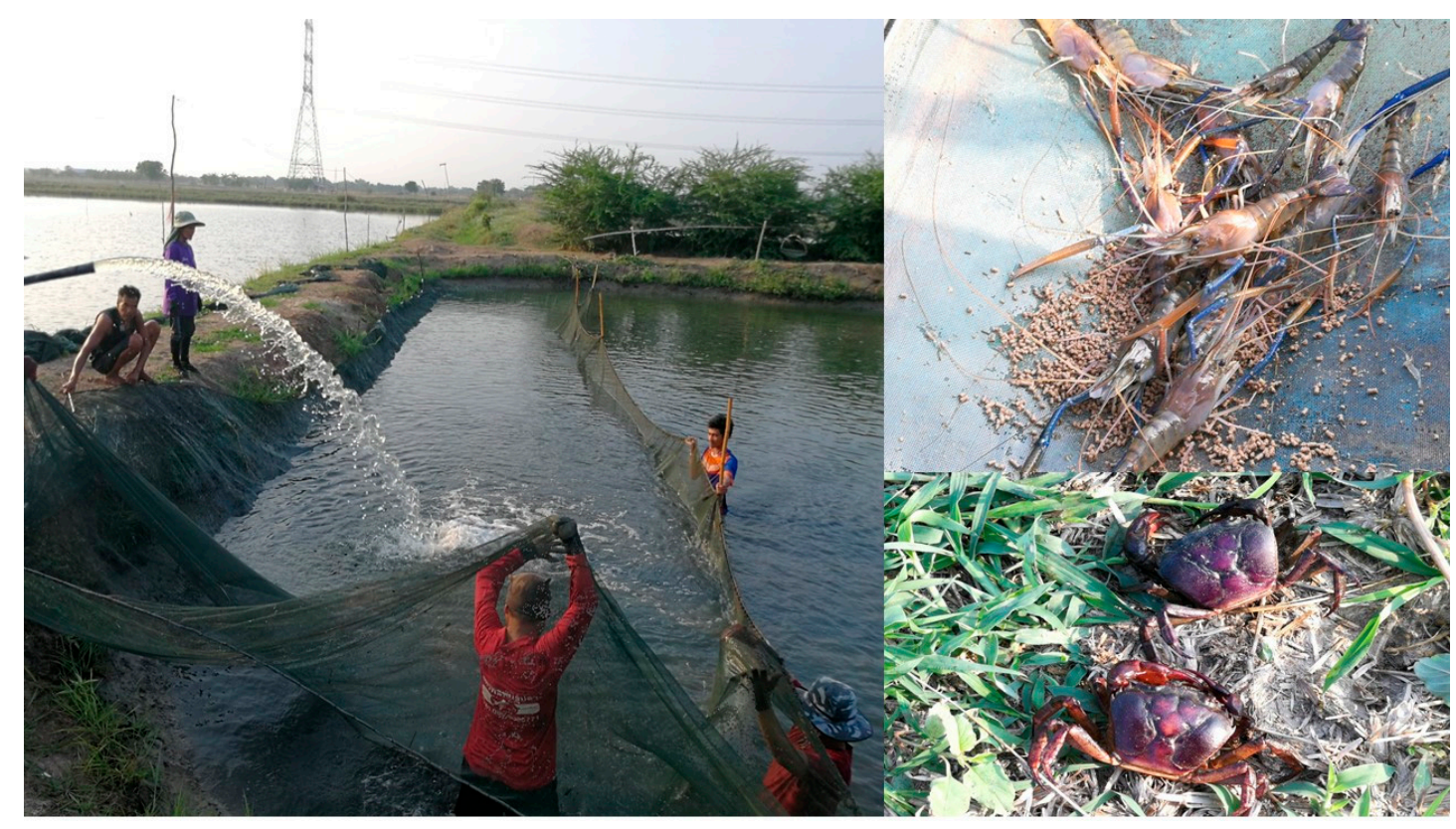

Figure 4. The local people at Nong Teen Nok are collecting prawns for sales and some crabs for personal use in the pond. Source: first author.

One of the participants (BP007) stated:

"They asked that everyone raise their hand if in the agreement of the ICD, during the public hearing every time. We recorded in the meeting that we do not agree but they reported that 
we agree. They told us that this is a good area to locate an ICD. I asked, why? They answered that it is near a railway station. Only a kilometer, it is easy to connect to the logistic system. I said the local people would make trouble, what should we do? However, they did not listen and provided no answers.".

Another motivating factor was the lack of proper communication and poor governance structure between the government and local people, as reflected by one participant (BP011):

"I rented the land here for a long time with trust. My husband just passed away, I am a single mom and taking care of my children ... who will help me...? They have not told us any solutions. They only told us the ICD project has to finish in 2024 and they have to provide the land and it should be cleared in 2021 for starting the project. However, they have not told us about compensation. If this area is ICD project, I will not get anything because of no documents".

Other participants were motivated by concerns relating to the approach that was adopted in the implementation of the EEC project. One participant (BP006, below) commented about the process employed by the Department of Public Works and Town and Country Planning to change the land use zone after the EEC project had well commenced. The department was able to make these changes as the EEC policy committee under the Eastern Special Development Zone Act has the authority to make decisions on the EEC project.

“The previous report of the Department of Public Works and Town and Country Planning is clear, this area is good for food production and it will not suit an industrial estate. This report was done as an academic report. However, the department structure has been changed and now relies on the EEC policy committee once the EEC project is started. As a result, the city plan has a new process in EEC areas. If the EEC policy committee points to any areas, the department must listen to them. This process may lead to injustice because they do not participate in civil society and lose the academic research in the city plan".

Finally, participants were motivated by concerns about a land takeover by the government and having to relocate to a new area. Their concern stems mostly from the loss of around 600-900 Rai (237-356 acres) of fertile agricultural land and abundant fish in the current area, which they will lose if they move (BP 008). Likewise, information about the EEC project was unclear about the floodway, which may impact on surface water and groundwater used for local people's livelihood (BP 017).

Particularly, participants from the middle and older age groups with low education and no technical skills were worried that they do not have the required skills to work in an industrial factory (BP 004).

"I would like to tell them that I finished grade 6 at school and am over 40 years, what can I do in a factory? I am unqualified to work there" (BP011).

The community organizing stage of motivation was evidenced in the data by the shared sense of injustice about the haste with which the policy was implemented; the idea of losing their source of livelihood, community, relationships, and identity; a sense of helplessness about not being adequately consulted or being part of the decision making process; as well as receiving confusing information from EEC officials. Bonding social capital is useful here to explain that in communities comprised of homogeneous relationships, that is, those with similar experience, people can have relations of thick trust [19]. This sense of thick trust is typical amongst families, or those with very close relations. Strong bonds enable people to band together to take collective action against perceived injustice impacting on their communities. 


\subsubsection{Community Building}

Community building occurred when members identified the issues and raised awareness of those, so others understood and gained knowledge about their shared problems. Due to a lack of answers or clarity from the EEC officials about the government's relocation plan, residents of Nong Teen Nok in the Ban Pho district formed a group (a community enterprise) to address their collective issues. Their community enterprise is a small business that shares its profits among its members, for the group's purpose.

\section{Sharing and Gaining Information}

Following their disagreement with the outcome of the public hearing process, members of Nong Teen Nok community, who were impacted by the government's decision to relocate them to a new area, began to share information and discuss amongst family members, work colleagues, neighbors, and friends in the community. The villagers shared knowledge, ideas, and information amongst themselves and other groups who were opposed to the construction of the industrial estate. Further, some villagers voiced their concerns through letters sent to the head of the district, the mayor and the head of the EEC office to gain more information and clarity about the government's plans.

Participants demonstrated a commitment to community building when they commented that they lived in this area for a long time and their relationships are like relatives. While villagers were facing the same problems, they helped each other by volunteering to send the letters to the mayor or by donating money to group activities that enabled them to be more equipped to take action (BP 007).

“... For sharing EEC information ... For example, today we have 50 participants in this meeting. I tell them directly ... I had documents for distribution and some volunteers from Bangkok came to help us ... I share to Facebook, online and every channel as much as I can" (BP006).

\section{Raising Awareness and Gaining Shared Knowledge About Agriculture and the EEC}

Another theme of community building was demonstrated by the need to raise awareness and gain knowledge about agriculture and the EEC. Members of one civil society group met and discussed informally amongst themselves, seeking a solution to their problems. They then met and shared experiences with other social groups inside and outside of the village, which helped create solutions to improve sales of their products and increase group members' income as well. For example, some of the members sought advice from the Natural Agriculture Centre in Chonburi province, which supports the Sufficiency Economy Philosophy (SEP) of the former King. The Centre formally provided the group from Nong Teen Nok with information on agricultural best practice knowledge, training, and ideas on shifting away from the use of chemicals in agriculture to sustainable agriculture. In addition, this process provided members of the relocation group with the opportunity to meet and share their experiences with other groups in an informal setting and encouraged engagement with youths.

"The activities of our community enterprise group is to diversify our products to various uses. We (community enterprise) provide a meeting point for our members and the opportunity to gain income through selling our products such as fish and prawns. These are produced by our members ... next month, we plan a youth activity to tell people about our problems and protecting our food land. We will invite young people in the community and university students from Bangkok will join us" (BP007).

"The youth activity this month ... I created to build up awareness and inform people about Nong Teen Nok's situation and educate young people about EEC in our village" (BP014).

The community organizing stage of community building was evidenced in the data through the gaining of, and sharing of information and knowledge amongst members of the group, as well as processes to raise awareness and collaborate. Collaboration with the group from Nong Teen Nok shows that they recognize the issues they face and are willing to find solutions by engaging with other 
groups across the wider community. This can be explained as bridging social capital. This is significant because building relationships with people without close pre-existing ties (such as homogeneous relationships in a family), and from diverse backgrounds or diverse geographical areas have the potential to lead to greater collaboration and impact with increased numbers. Putnam (2000) theorized that thin trust relationships are those that assist with community development processes. Given that the Nong Teen Nok is a significant food production region for Thailand and through export, the world, a greater number of people involved in collective action has the potential to influence power holders such as the EEC policy makers. Additionally, the local group not only communicated through physical or face-to-face meetings but also connected online to share EEC information and organize planning meetings to resist the EEC project in their area.

\subsubsection{Planning}

The planning stage of community organizing involves members developing plans and setting goals. One civil society group that is a community enterprise formed a common goal to remain united and refused to be relocated to a new area given the uncertainty of whether the new settlement being offered by the government would be fertile enough for food production. The villagers met for about three months planning and strategizing, gaining the support of others and then coming up with the idea of setting up a community enterprise as a means of protecting their land and food security.

Gaining Allies

The group sought ideas about how to engage in their resistance strategy from various external sources such as academic institutions, as well as liaising with other civil society groups in the Bangkhla district, who in the past, had experienced and led a successful movement against the construction of a coal power-plant in their district. The group also developed connections and exchanged learnings and shared experience with the people in Chonburi province (another target area for the EEC projects) who were experiencing similar issues (BP 011).

Participants described their ways to gain allies, which also included an invitation to the researcher:

"Next week, we will have a meeting for a ceremony of the royal coronation of King Maha Vajiralong Kone (the new king since 2016). I invited Mr K (alias) he is a CCS civil society member from Bang khla. Do you know him? If you have time, I will invite you too" (BP007).

The data has shown that the community organizing stage of planning has been evidenced in this example from the community enterprise members who came together to develop an action plan to resolve their concerns with a united commitment to refuse relocation. To achieve this goal, the group became an active voice/contributor in seeking solutions to the problems they face rather than being passive recipients of the government's relocation plan. Through their collective alliance, the group's actions can also be seen as drawing on bridging social capital where they built relationships across other geographical regions and connected with a range of sectors to gain knowledge, support, and information in the hope of achieving a positive outcome for their community.

\subsubsection{Mobilizing}

At the mobilizing stage of community organizing, community members build their power using various tactics, including negotiation with policymakers to achieve their goal. The community enterprise group discussed in the previous section was formed as a response to the land acquisition carried out under the EEC project. The group mobilized members to engage with the wider community and sympathetic groups through symbolic activities such as tree planting exercises during the royal coronation of King Rama X, showing their alignment with the SEP of the late King Bhumibol's initiative, which was still supported by the current government. Members also gained support by using tactics of engaging with politicians, such as a Member of Parliament (MP) from an opposing party as well as the Deputy Minister of Agriculture and Cooperatives (who was born in Ban Pho district). 


\section{Linking to Decision-Makers for Protecting the Land}

The villagers sought solutions through engaging with decision-makers. For instance, when the Prime Minister (PM) came to visit CCS on 20 March 2019 some members of a community enterprise in Nong Teen Nok area presented a letter of concern about EEC impacts in their area. Although the PM received the letter, the villagers were not confident that he would read it or listen to them. The community enterprise group organized meetings and provided regular updates to members to keep up the momentum.

The community enterprise group also had a member of a civil society group knowledgeable about the EEC Act consult with a Human Rights group to provide support to the villagers impacted by the EEC project.

A few months later, the community enterprise group organized a World Environmental Day activity and invited the Deputy Minister of Agriculture and Cooperatives (at that time) to the opening ceremony of the community enterprise centre at Nong Teen Nok, Ban Pho. This was a significant event for the people of Nong Teen Nok as the representative of EEC, the head of the district, many journalists and press were in attendance. The Deputy Minister during the media interview publicly emphasized that Ban Pho is one of the best areas to plant rice and have a fishery, demonstrating his local knowledge. He was also empathetic to the community's concerns.

"I consulted a lecturer who is supporting us. He has worked with the Deputy Minister of Agricultural and Cooperatives. I invited him to open our centre today (World Environmental Day). He asserts that our land is abundant and it should not become an industrial area.... I believe that this message will help us ...." (BP007).

The data shows that the community organizing stage of mobilizing is evidenced by the people of Nong Teen Nok who increased and mobilized their networks. They sought to protect their land by linking with policy actors and the decision-makers. The impact of their actions can be explained through linking social capital, illustrated by the nature of social interactions between the community and other agencies, authorities, and policy actors at various levels. For example, the election of a local MP to parliament during the general election (March 2019) can serve as a powerful voice to represent the Ban Pho community at policy levels. In addition, the Deputy Minister of Agriculture and Cooperatives is a key person who can use his influence to contact directly with the EEC policy committee. By mobilizing in the way they did, they sought to influence policy development so that potential negative impacts on their communities could be ameliorated.

\subsubsection{Outcome Report}

The final stage of the community organizing process is where members report the results of their actions. During community enterprise meetings, members were given updates on income and expenditure, and new updates on the EEC projects. The financial report shows the transparency and multiple functions of members as below.

"I am a volunteer accountant in this group; I report on the expenditure of our group. For example, if we get donation around 14,000 THB (467 USD) for hiring vans to go to EEC office or demonstration, I have to make enquiries on how much does it cost to hire vans and fuel it to and from, and then report back to our members when we come back" (BP014).

Furthermore, members who had sought assistance from a knowledgeable lawyer informed other members how to legally and carefully protest to the government. Information was shared by members, who attended events and groups within other districts. Through the sharing of these updates, members brainstormed and developed a plan for the next course of action such as peaceful activities and share information from the lawyer (BP 011). In June 2019, the community enterprise group was informed by a member who attended a public hearing of EEC, that the ICD project in the Nong Teen Nok area had stalled as a result of their action. However, as this is only temporary the group continues to plan and 
organize activities to unify and connect members through events such as the sale of their products in the village and at a food festival at the university. The strategy is to promote CCS as a province of food, to increase its involvement with the university; and to share information online with their members.

The data has shown that the community organizing stage of reporting outcomes among network members is crucial for monitoring and evaluating strategies. Reporting helps group members to keep abreast of evolving and dynamic situations, to seek new ideas and can help instill in members a sense of togetherness or purpose towards the collective goal. Effective reporting requires transparency in all areas that relate to group activity and fosters accountability and trust in the group.

\subsection{Discussion}

This research demonstrates the role social capital plays in the process of community organizing in the context of natural resource management. Land is a prized asset (whether in an economic, physical, or cultural sense) for many people around the world and the loss or fear of losing this asset without free, informed, prior consent can be perceived as an injustice. More so, many communities do not have legal title to their land although they may have customary or informal land rights.

In our study, the residents of Ban Pho district are highly motivated to band together and form alliances due to the potential loss of their land considering that some of the villagers lease the land based on trust with no documented proof. As such, if they are to lose the land, they are not eligible for compensation. Their only option is to band together and fight to protect the land. This resulted in the affected villagers connecting to others with similar experiences to build trusting relationships and collective power. This is significant given that not every community takes this stance, to band together to fight economic policy implementation.

Through bonding, bridging, and linking forms of social capital, residents of Ban Pho district took proactive steps to make known their concerns to policy actors and decision makers about potential impacts that the implementation of the EEC project will have for the residents and their community. Whilst their community organizing efforts might not lead to a favorable outcome from their perspective such as the government rescinding its plan to build an ICD in Nong Teen Nok area, the stalling of the ICD project at this stage is testament to the community's influence. The local community group understood that to affect change, or slow down the process of change, they needed to band together with other groups and build relationships beyond just those they were close to (bonding capital). Thus, they grew their bridging and linking social capital relationships [18] with other social groups, political actors, and decision makers with agency/power to support their cause and influence policy. The results demonstrate evidence of the integration between 'trust' in social capital concepts developed by Putnam [18] and 'power' in people as articulated by Alinsky in community organizing processes $[15,17]$, which has led to the protection of land and food production.

The Thai Government Economic policy made without due consideration for, and in consultation with its citizens, can have negative impact on local people, such as the loss of livelihood and reduced social connections and networks. From our study, we found that rapid economic policy can impact on land use and food security and create the loss of trust amongst the citizenry. Our results show that the local farmers whose source of income and livelihood is dependent on the land and river are highly vulnerable to losing their land to EEC projects [41]. Rapid policy changes can lead to poor governance, such that effective community engagement and transparent communication is reduced or even, non-existent. This gives the people little time and/or resources to adapt. A better approach is administering principles of good governance through legitimacy, transparency, accountability, inclusiveness, fairness, integration capability, and adaptability [58].

However, one possible reason for the minimal engagement and effective communication between the government and the community members may be due to the rapid development and implementation of the EEC policy (the EEC project and Eastern Special Development Zone Act were created during a military coup), which did not allow room for civil-society representatives on the EEC policy committees nor opportunity for enquiry or investigations from the civil society. 
Another key finding from this study, is the minimal engagement and involvement of Ban Pho residents in the decision-making process despite potential impact if the EEC projects are implemented. One reason for this minimal engagement, according to the EEC officials, is due to the rapid implementation of the policy in the EEC targeted areas, which provided the officials with little time to organize appropriate levels of community engagement. This suggests a limited understanding of the benefits of participatory community engagement: effective community engagement can often reduce opposition and prevent delays in development over the long term. Bottom-up community engagement by government could shift a coercive approach to more of a partnership approach to achieve complementary goals with citizens [59-63]. Fisher (2012) suggests that the key to successful community participation is through trust-building by parties involved and devolution of power from the top (decision-makers) to the bottom (local community). Although the method, form, or level of community engagement can differ based on the context (cultural, political, social, and economic setting), a key criteria is the extent to which a community has equality in the exchange of information, power, and/or shared responsibility [59].

Finally, food is a basic human need and the fear of losing access to the region's abundant agricultural land and fisheries led to a community organizing response, i.e., the use of people power to seek a solution to an issue by protecting their land [11]. This fear was justifiable because of the knowledge of land acquisition [64], water grabbing, and pollution associated with development of other industrial estates [47]. It resulted in a lack of confidence in the EEC project. In this case study, a key tactic used by the villagers was to organize various activities, such as planting trees that support the SEP (aligned with the National Economic Development Plan); the SDGs; as well as the role of food security and agriculture in national economic development [65]. The tactic of showing alignment to government policy assisted their negotiations.

The Thai government perceives that economic growth through EEC project is essential, and focuses on SDG Goals 8 and 9. However, the project has the potential to negatively impact land use, food production, livelihoods, and community residents, with implications for achieving other SDG Targets. Specifically, the EEC project can affect the achievement of SDG Goals 2, 3, 6, 11, and 12 [66]. Thus, minimizing negative economic impacts will require supporting the agricultural sector whilst seeking alternative solutions to drive the country's economic development agenda over a longer term.

To protect land and food security, the SDGs provide a good basis for educating people and building awareness through social capital in community organizing activities at multiple levels.

\section{Conclusions}

The government's lack of engagement and involvement of local community members in the decision-making process in the twenty-year national economic growth policy, Thailand 4.0, to promote innovation and stimulate international investment through the Eastern Economic Corridor (EEC) project led to a lack of support by the affected communities. To address the potential impact of the EEC project, including loss of their farmland and means of livelihood, environmental (water, air, and noise pollution), socio-cultural (lifestyle, networks and relationships, and value system), the residents of Ban Pho responded by using the five stages of community organizing (motivation, community building, planning, mobilizing, and reporting) to protect their land and achieve food security. Meanwhile, they built three types of social capital (bonding, bridging, and linking) to strengthen their networks of relationships and increase their power to affect change.

This study shows that a high level of motivation (such as the potential loss of one's income/livelihood) is vital for motivating community organizing processes, which require an ongoing commitment from members to influence decision-makers. The research shows the benefit of building on existing social capital for effective community organizing.

The agricultural sector is an essential source of livelihood, employing $30.9 \%$ of labor in Thailand [67]. The sector is highly vulnerable and experiences a significant wealth gap compared to other sectors [67]. Thus, based on the results and findings from this research, adequate engagement with all stakeholders 
is necessary in managing natural resources [58] and can help to build trust, gain citizen's support, and reduce conflicts. As such, policymakers and those involved in decision-making at the macro level need to consider positive approaches to participatory community engagement, good governance, and trust-building in the development and implementation of economic policies.

Further, rapid development processes can impact local communities negatively. They provide little time and resources to allow for adaptation and minimize the negative impacts of the policy. We argue that the government should slow down its policy implementation process, engage better with the local communities to investigate, and understand their concerns and fears, and put in place transition strategies. One way the government can achieve this is to create feedback loops, such as involving members of civil society groups in the EEC committees at the policy level and engaging with members of the community at the grassroots level. Additionally, listening to the concerns of youth, who will inherit problems, would be a good start to a more just process aligned with the SDGs.

Finally, this research contributes to both community development practice and academic knowledge: (a) the motivation and tactics used to stall a large project in the context of a lack of participatory engagement by government provide lessons for others in similar situations; and (b) the unique deconstruction of community actions through the analysis of the role and benefits of social capital provides deeper understanding and insight into community organizing.

Author Contributions: Conceptualization, methodology, formal analysis, investigation, writing original draft-P.C.; writing-review and editing, C.B., A.L., N.I.; supervision, C.B., A.L.; project administration, C.B.; funding acquisition, P.C. All authors have read and agreed to the published version of the manuscript.

Funding: This research was funded by Mahasarakham University, Thailand, and University of the Sunshine Coast, Australia as part of a PhD research program.

Acknowledgments: The authors acknowledge the contribution of the research participants and community members of Nong Teen Nok; civil society groups; local government officers; and members of the business sector in Ban Pho district of Chachoengsao province, Thailand.

Conflicts of Interest: The authors declare no conflict of interest.

\section{References}

1. Amadeo, K. ARRA, Its Details, With Pros and Cons: What Did ARRA Really Do? Available online: https://www.thebalance.com/arra-details-3306299 (accessed on 13 February 2020).

2. Royal Thai Embassy, Washington D.C. Thailand Taking 4.0 Regional as ASEAN Chair. Available online: https: //thaiembdc.org/2019/02/18/thailand-taking-4-0-regional-as-asean-chair/ (accessed on 6 December 2019).

3. Keulen, H.; Kuyvenhoven, A.; Ruben, R. Sustainable land use and food security in developing countries: DLV's approach to policy support. Agric. Syst. 1998, 58, 285-307. [CrossRef]

4. McMichael, P. Food security, land, and development. In The Palgrave Handbook of International Development; Springer: Berlin/Heidelberg, Germany, 2016; pp. 671-693.

5. Gandhi, V.P.; Zhou, Z. Food demand and the food security challenge with rapid economic growth in the emerging economies of India and China. Food Res. Int. 2014, 63, 108-124. [CrossRef]

6. Edward, C. Food Security: Concepts and Measurement. Available online: http://www.fao.org/docrep/005/ y4671e/y4671e06.htm (accessed on 1 June 2018).

7. Rulli, M.C.; Saviori, A.; D'Odorico, P. Global land and water grabbing. Proc. Natl. Acad. Sci. USA 2013, 110, 892-897. [CrossRef]

8. Gasteyer, S.; Isaac, J.; Hillal, J.; Hodali, K. Water grabbing in colonial perspective: Land and water in Israel/Palestine. Water Altern. 2012, 5, 450.

9. Harris, P.; Thompson, O. Lessons to Improve Community Engagement for Natural Resource Management-A Case Study. Available online: http://www.regional.org.au/au/apen/2005/4/2778_harrisp.htm (accessed on 13 February 2020).

10. Lathouras, A. A critical approach to citizen-led social work: Putting the political back into community development practice. Soc. Altern. 2016, 35, 32-36.

11. Brady, S.R.; O'Connor, M.K. Understanding how community organizing leads to social change: The beginning development of formal practice theory. J. Community Pract. 2014, 210-226. [CrossRef] 
12. Christens, B.D.; Inzeo, P.T.; Faust, V. Channeling power across ecological systems: social regularities in community organizing. Am. J. Community Psychol. 2014, 53, 419-431. [CrossRef]

13. Brown, M.J. Community Organizing; Sage Publication: Newbury Park, CA, USA, 2010.

14. Mandell, J. Picnics, participation and power: Linking community building to social change. Community Dev. 2010, 41, 269-282. [CrossRef]

15. Phulwani, V. The poor man's machiavelli: Saul alinsky and the morality of power. Am. Political Sci. Rev. 2016, 110, 863-875. [CrossRef]

16. Gittell, R.; Vidal, A. Community Organizing: Building Social Capital as a Development Strategy; Sage Publications: Newbury Park, CA, USA, 1998.

17. Alinsky, S.D. Rules for Radicals: A Practical Primer for Realistic Radicals; Vintage Books: New York, NY, USA, 1989.

18. Putnam, R.D. Bowling Alone: The Collapse and Revival of American Community; Simon and Schuster: London, UK, 2000.

19. Putnam, R.D. The prosperous community. Am. Prospect. 1993, 4, 35-42.

20. Osborne, C.; Baldwin, C.; Thomsen, D. Contributions of social capital to best practice urban planning outcomes. Urban Policy Res. 2016, 34, 212-224. [CrossRef]

21. Jones, N. Environmental activation of citizens in the context of policy agenda formation and the influence of social capital. Soc. Sci. J. 2010, 47, 121-136. [CrossRef]

22. Perkins, D.D.; Hughey, J.; Speer, P.W. Community psychology perspectives on social capital theory and community development practice. Community Dev. 2002, 33, 33-52. [CrossRef]

23. Islam, M.K.; Merlo, J.; Kawachi, I.; Lindström, M.; Gerdtham, U.G. Social capital and health: Does egalitarianism matter? A literature review. Int. J. Equity Health 2006, 5, 1-28. [CrossRef]

24. Woolcock, M.; Narayan, D. Social capital: Implications for development theory, research, and policy. World Bank Res. Obs. 2000, 15, 225-249. [CrossRef]

25. Woolcock, G.; Manderson, L. Social Capital and Social Justice: Critical Australian Perspectives; Charles Darwin University Press: Brinkin, Australia, 2009.

26. Talbot, L.; Walker, R. Community perspectives on the impact of policy change on linking social capital in a rural community. Health Place 2007, 13, 482-492. [CrossRef]

27. Brown, D.L.; Schafft, K.A. Rural People \& Communities in 21st Century; Polity Press: Cambridge, MA, USA, 2011.

28. Osborne, C. Social capital and knowledge cities: emphasising new epistemological frameworks for sustainable societies in urban planning. In Proceedings of the 6th Knowledge Cities World Summit, Istanbul, Turkey, 9-13 September 2013; pp. 45-56.

29. Anderson, G.; Blair, R.; Shirk, J.J.C.D. Neighborhood associations and community development: Differences in needs and strategies. Community Dev. 2018, 49, 504-521. [CrossRef]

30. MacLeod, J.; Byrne, C.E. It's only a garden: A journey from community building to community organising and back again. New Community Q. 2012, 10, 36-44.

31. Warren, M.R. Community organizing in Britain: The political engagement of faith-based social capital. City Community 2009, 8, 99-127. [CrossRef]

32. Armstrong, A.; Banks, S. Organizing for change: North tyneside community development project and its legacy. Community Dev. J. 2017, 52, 290-312. [CrossRef]

33. Norander, S.; Galanes, G. "Bridging the Gap": Difference, dialogue, and community organizing. J. Appl. Commun. Res. 2014, 42, 345-365. [CrossRef]

34. Wongsintuwiset, P.J.N. Middle Income Trap; Bank of Thailand: Bangkok, Thailand, 2017; pp. 1-4.

35. Ministry of Industry Thailand. Eastern Economic Corridor Development Project. Available online: http://www.boi.go.th/upload/EEC\%20pack\%20for\%20BOI\%20fair_Rev4\%203\%201.pdf (accessed on 20 February 2018).

36. Pangsapa, P. Environmental justice and civil society. In Routledge Handbook of Environment and Society in Asia; Routledge: Abingdon, UK, 2014.

37. Matthews, N. Water grabbing in the mekong basin-an analysis of the winners and losers of Thailand's hydropower development in lao PDR. Water Altern. 2012, 5, 392-411.

38. Kirchherr, J. Strategies of successful anti-dam movements: evidence from Myanmar and Thailand. Soc. Nat. Resour. 2017, 31, 166-182. [CrossRef] 
39. Adger, N.W.; Kelly, M.P.; Huu Ninh, N. Environment, Society and Precipitous Change, 1st ed.; Routledge: London, UK, 2001.

40. Costa-Böddeker, S.; Hoelzmann, P.; Thuyên, L.X.; Huy, H.D.; Nguyen, H.A.; Richter, O.; Schwalb, A. Ecological risk assessment of a coastal zone in Southern Vietnam: Spatial distribution and content of heavy metals in water and surface sediments of the Thi Vai estuary and Can Gio mangrove forest. Mar. Pollut. Bull. 2017, 114, 1141-1151. [CrossRef]

41. Thi, N.P.; Kappas, M.; Faust, H. Improving the socioeconomic status of rural women associated with agricultural land acquisition: A case study in Huong Thuy Town, Thua Thien Hue Province, Vietnam. Land 2019, 8, 151.

42. Dijk, M.R.M.V.; Rooij, W.V.; Hilderink, H. Land use dynamics, climate change, and food security in Vietnam: A global-to-local modeling approach. World Dev. 2014, 59, 29-46.

43. Chachoengsao Provincial Satistical Office. Chachoengsao Provincial Statistical Report. Available online: http://chchsao.nso.go.th/index.php?option=com_content\&view=article\&id=560:2561\&catid=102\& Itemid=507 (accessed on 20 June 2019).

44. Bordalo, A.A.; Nilsumranchi, W.; Chalermwat, K. Water quality and uses of the Bangpakong river (Eastern Thailand). Water Resour. 2001, 35, 3635-3642. [CrossRef]

45. Eastern Economic Corridor Office. The Potential of Chachoengsao Chonburi Rayong. Available online: https://www.eeco.or.th/pr/news/EECFocusThePotentialOfChachoengsaoChonburiRayong (accessed on 26 November 2019).

46. Aksonkij, A. EIC Analysed the Long Term "Water Stress" in EEC Areas. Available online: https://thaipublica. org/2018/06/eic-sec-eec-water-scarcity/ (accessed on 16 October 2018).

47. ASTV News. Water Grabbing in Rayong, Thailand. Available online: http://www.manager.co.th/local/ viewnews.aspx?NewsID=9580000073897 (accessed on 7 September 2017).

48. Mounce, E. Boon Mar Ponds: Barramundi Fishing in Thailand. Available online: https://www.fishthailand. co.uk/boon_mar_ponds.html (accessed on 6 December 2019).

49. Division of Rice Research and Development Thailand. History of Jasmine Rice; Rice Department Thailand: Bangkok, Thailand, 1954.

50. Chachoengsao Industry Office. The Economy and Industry Report in Chachoengsao; Ministry of Industry: Chachoengsao, Thailand, 2017.

51. Eastern Economic Corridor Office. Eastern Economic Corridor Act B.E. 2561 of Thailand. Available online: https://www.eeco.or.th/en/content/eastern-special-development-zone-act (accessed on 4 November 2018).

52. Vachiravit, L. Nong Teen Nok People and Mr. Srisuwan Chanya against the ICD in Chachoengsao and Tell EEC Project Is Unconstitutional. Available online: https://www.nationtv.tv/main/content/378733597/ (accessed on 13 February 2020).

53. Jotikasthira, O. Chachoengsao to Get New Inland Container Depot. Available online: https:// www.bangkokpost.com/business/1504630/chachoengsao-to-get-new-inland-container-depot (accessed on 13 February 2020).

54. Tangjaisatapat, P. Sustainable Development and EEC. Available online: http://thailand.prd.go.th/1700/ewt/ aseanthai/ewt_news.php?nid=8337\&filename=index (accessed on 20 September 2018).

55. Eastern Economic Corridor Office. Development Goals. Available online: https://www.eeco.or.th/en/content/ development-goals (accessed on 6 December 2019).

56. Yin, R.K. Case Study Research Design and Methods, 4th ed.; Sage Publications: London, UK, 2009; Volume 5.

57. Creswell, J.W. Research Design: Qualitative, Quantitative, and Mixed Methods Approaches; Sage Publications: London, UK, 2003.

58. Lockwood, M.; Davidson, J.; Curtis, A.; Stratford, E.; Griffith, R.J.A.G. Multi-level environmental governance: Lessons from Australian natural resource management. Aust. Geogr. 2009, 40, 169-186. [CrossRef]

59. Rocheleau, D.E. Gender, ecology, and the science of survival: Stories and lessons from Kenya. Agric. Hum. Values 1991, 8, 156-165. [CrossRef]

60. Prager, K.; Vanclay, F. Landcare in Australia and Germany: Comparing structures and policies for community engagement in natural resource management. Ecol. Manag. Restor. 2010, 11, 187-193. [CrossRef]

61. Tennent, R.; Lockie, S. Vale landcare: The rise and decline of community-based natural resource management in rural Australia. J. Environ. Plan. Manag. 2013, 56, 572-587. [CrossRef] 
62. Fisher, R. Learning through action: Reflections on action research in natural resource management. In Adaptive Collaborative Approaches in Natural Resource Governance; Routledge: Abingdon, UK, 2012; pp. 275-304.

63. Ojha, H.R.; Hall, A.; Sulaiman, V.R. Adaptive Collaborative Approaches in Natural Resource Management: Rethinking Participation, Learning and Innovation; Routledge: London, UK, 2012.

64. Margulis, M.E.; McKeon, N.; Borras, S.M., Jr. Land grabbing and global governance: Critical perspectives. Globalizations 2013, 10, 1-23. [CrossRef]

65. National Economic and Social Development Board. The Twelfth National Economic and Social Development Plan (2017-2021); Office of the Prime Minister Thailand: Bangkok, Thailand, 2017.

66. The United Nations. The United Nations Sustainable Development Goals. Available online: http://www.un.org/sustainabledevelopment/blog/2015/12/sustainable-development-goals-kick-offwith-start-of-new-year/ (accessed on 1 June 2018).

67. Jantarat, S.; Sangimnet, B.; Uttawanij, V. Focus on Agriculture structure: How Is It Changed from the Past to the Future? Available online: https://www.pier.or.th/wp-content/uploads/2018/05/aBRIDGEd_2018_009.pdf (accessed on 26 November 2019).

(C) 2020 by the authors. Licensee MDPI, Basel, Switzerland. This article is an open access article distributed under the terms and conditions of the Creative Commons Attribution (CC BY) license (http://creativecommons.org/licenses/by/4.0/). 